\title{
Immigration and the Expanding U.S. Southern Border: Casa en tierra ajena (2016)
}

Ewa Antoszek

\section{OpenEdition}

\section{Journals}

Electronic version

URL: https://journals.openedition.org/ejas/16822

DOI: 10.4000/ejas.16822

ISSN: 1991-9336

Publisher

European Association for American Studies

\section{Electronic reference}

Ewa Antoszek, "Immigration and the Expanding U.S. Southern Border: Casa en tierra ajena (2016)", European journal of American studies [Online], 16-1 | 2021, Online since 27 April 2021, connection on 08 July 2021. URL: http://journals.openedition.org/ejas/16822 ; DOI: https://doi.org/10.4000/ejas.16822

This text was automatically generated on 8 July 2021 .

Creative Commons License 


\title{
Immigration and the Expanding U.S. Southern Border: Casa en tierra ajena (2016)
}

\author{
Ewa Antoszek
}

1 The question of the U.S.-Mexico border has been discussed extensively by various media in different contexts, particularly within the last few years. The debate concerns both the border as the political line dividing two nation-states, its physical marker-the infamous wall-as well as the life of those who live in its shadow and have to face the challenges it posits on a daily basis. There is also a separate category of newspaper articles and reports that address the question of migration across the border and the plight of undocumented migrants both in the U.S and on their way to fulfill el sueño americano. These publications in turn can be divided into several subcategories, each of which refers to a particular problem related to the immigration across the U.S.-Mexico border, including legislative issues, or what Jeffrey Toobin calls aptly the "American Limbo" (30), militarization of the border and the resulting criminalization of migrants, or the growing number of deportations and conditions in detention centers, to mention just the most frequently appearing themes.

2 Those exemplary cases of border stories related recently in the media signal the shift in immigration patterns from Central America and consequences of those changes for the whole region. They also demonstrate the trajectory of transformations at the U.S.Mexico border, including the change of the concept of the border from la línea separating two nation-states into an ever-expanding zone that exceeds political lines and turns Mexico into the great south border. Those issues are also the focus of the documentary Casa en tierra ajena or Home in a Foreign Land (2016) ${ }^{1}$ based on the book No más muros. Exclusión y migración forzada en Centroamérica (Exclusion and Forced Migration in Central America: No More Walls) by Carlos Sandoval García and directed by Ivannia Villalobos-Vindas. The purpose of this article is twofold: to examine how VillalobosVindas represents the complexity of the process of forced migration from Central America and to analyze how the documentary illustrates the appearance of the 
expanding border or the transformation of the U.S.-Mexico political line into the great south border, as it is often called.

3 As Michael R. Ogden notes in his analysis of interactive and transmedia documentaries, "[t]he goal of actuality storytelling (reality-based or factual stories; i.e. documentary and journalism) has always been to 'tell life,' to reveal to the audience the stories hidden in the eyes the 'Other," regardless whether one adopts Robert Flaherty's or John Grierson's definitions of the documentary genre (122). Ogden argues that, though different, those two views on a documentary have a shared denominator, namely " $[\mathrm{t}] \mathrm{he}$ common goal of both approaches-and those in between-is to bring audiences as close to events as possible, to have them experience the story" (122) and therefore, "[f]or many documentarians and journalists, the raison d'être for telling stories is to create an emotional connection with the audience and hopefully, stimulate insights and encourage or influence action" (122). Ogden's conclusions about general documentary functions fit the description of Casa en tierra ajena that tells the complex and multifaceted story of forced migration from the Northern Triangle, encouraging the viewer not only to interpret this account, but also to become more of what Axel Bruns calls "the produser" (qtd. in Ogden 125), owing to the film's transmedia form.

Casa en tierra ajena is a coproduction of University of Costa Rica (UCR), La Universidad Estalal a Distancia (UNED) and Consejo Nacional de Rectores (CONARE), providing financial support (Villalobos-Vindas 88). As mentioned above, the documentary is based on Carlos Sandoval García's book and as such the narrative explores the issues discussed in No más muros, including the factors of expulsion, obstacles and dangers the migrants face on the way to the U.S. and policies of migration control as well as strategies of solidarity. However, since the film is not an adaptation per se, it diverges from the book and Villalobs-Vindas addresses the abovementioned issues in a particular way, not only examining the character of migration from individual countries of the Northern Triangle and thus turning it into a subregional analysis, but also illustrating historical facts with personal stories.

5 The process of film-making was relatively long, as it took the crew three years to collect and record the materials; they covered about 4,000 kilometers in five countries: Costa Rica, Nicaragua, Honduras, El Salvador, and Mexico. The resulting material was subsequently divided into three major parts, each of which discusses a specific migration-related issue. As Ivania Villalobos-Vindas reveals in her article on the production of Casa en tierra ajena, the film addresses three major questions/issues inspired by Sandoval García's book: "Why do people migrate? Mechanisms of control of migration and travel dangers/hazards; and hospitality without borders" (93). Consequently, the documentary is divided into three parts, each of which corresponds to the questions posed by the book: Part One, "El derecho a no migrar" ("The right not to migrate") explores the reasons behind forced migration from the Northern Triangle; Part Two, "El derecho a tener derechos" ("The right to have rights") investigates abuses and perils the migrants face in transit and at the final border crossing to the U.S., with a particular focus on the growing numbers of human rights' violations in Mexico, as the transit country. Part Three, "El derecho a la esperanza" ("The right to hope") was planned to counter the pessimistic undertone of the previous parts, at least to some extent-it discusses the issue of hospitality migrants experience on the example of migrants' shelters located along the routes to the north. 
6 In the director's words, the film is the response to the growing need to "convey social scientific research through audiovisual language" (Villalobos-Vindas 89), as, transformed into a documentary the research is more accessible to wider audiences. Making the film Villalobos-Vindas was also motivated by the necessity to conduct a comprehensive examination of the issue of migration from Central America, due to the seriousness of this phenomenon and in the light of prevalence of negative discourses regarding migration nowadays in general and immigration from Central America to the U.S. in particular, both to understand the reasons for this large-scale mobility and to defy stereotypical and superficial representations of migration in literary and cultural productions. Owing to such an approach, Casa en tierra ajena aims to provide a systematic analysis of the question of immigration from Central America, identifying both similarities and differences between individual "expelling" countries and at the same time examining the situation in the whole region, which is in a way historically preconditioned, especially with regards to the history of American interventionism in Central America, but which often gets disregarded in discussions on the northbound migration to the U.S. In this way Casa en tierra ajena makes invisible processes visible, relating the complexity of migrant experience and aptly illustrating the long-lasting interdependence of personal and political.

7 Francisco Cantú, a former Border Patrol agent and the author of The Line Becomes a River: Dispatches from the Border, in a PBS interview argues that "when you look at the media coverage around immigration, immigrants are always represented as this indistinguishable mass of people ... that's threatening the nation, or that's surging and overflowing at our borders" (5:37), which has a largely dehumanizing effect ("Francisco Cantú: 'The Line Becomes a River'”). In Casa en tierra ajena Villalobos-Vindas challenges such a representation of immigration and migrants, not only through a complex examination of immigration-related data, analysis of push and pull factors, or legislation around immigration, but also by giving voice to those who have actually gone through the migration-related ordeals. Such an approach of mixing the official data, fragments of documentaries covering historical events in the Northern Triangle leading to migration, and personal testimonies can be noticed in all three parts of the documentary.

8 Already the beginning of the film suggests that it is not going to be yet another typical migration-related documentary. Casa en tierra ajena opens with the information about the number of people who have migrated from Central America, which is four times the percentage of migration worldwide, and its main destination is the United States. Sheer numbers provided at the beginning of the first part, entitled significantly "El derecho a no migrar" are obviously in line with the official accounts and statistics that usually provide such numbers, thus relegating people who are signified by those numbers to the margin. However, in Casa these pieces of information are overwritten on the predawn scene with a tiny cottage somewhere on the hill in what we may assume is a town in Central America. The time of the day justifies grayish, de-saturated colors, yet at the same time it introduces bleak, depressing and melancholic atmosphere, as if foreshadowing that the events to come will be of pessimistic character/nature. It is also interesting that the cottage is shown from across a provisional fence surrounding the house and made of barbed wire, which, owing to the framing comes to the foreground. The barbed wire around the house serves to protect its inhabitants, yet it immediately evokes connotations with all the border markers-fences, barriers and walls which, 
serving to protect integrity of nation-states, separate and divide neighboring countries in a hurtful way. The wire can be inevitably associated with the barbed and concertina wire placed to reinforce the U.S-Mexico border fence, which Kelly Lytle Hernández describes as the "wartime materiel" (qtd. in Cantú 75) reused in what Victoria Hattam calls the process of "imperial recycling" (qtd. in Cantú 75).

The next scene presents a woman preparing for a trip-getting dressed, packing some staple necessities, tucking some medicines and wads of banknotes into her jeans and looking pensively at a photograph of a little girl-most probably her daughter-that is placed together on top of the cupboard with the holy medal of la Virgen de Guadalupe. The girl is going to be left behind-both literally by her mother and metaphorically from the protection of the saint. There is a moment of hesitation when the woman closes the gate and holds tightly to its rods, but she continues her trip and the next scene shows her looking back at her home town waking up in the valley, as if bidding farewell to those who stay. Then the title Casa en tierra ajena appears on the screen aptly suggesting that those new houses in the foreign land-if they ever get constructed-will never become homes, as home is what is left behind and oftentimes lost.

These opening scenes suggests that the stories Villalobos-Vindas relates are not going to be solely political tales accounting for the forced migration from Central America, but they will include personal narratives as well. First of all, such an approach allows to avoid dehumanization of the experience and people who go through that ordeal. It is no longer the aforementioned masses, or surges, or the infamous caravans, but real people whose situation allows the viewer to sympathize with. Apart from that, the story of their journey is an allegory of other migrant stories, as those potential border crossers from the opening scenes will reappear throughout the film and the account of their trip can easily become other migrants' story. Thus Villalobos-Vindas both acknowledges that each migrant tale is different, and yet there numerous factors which make this experience universal. It has to be mentioned here that, since VillalobosVindas objected to oversimplification and sentimentalism in a discussion of the topic of forced migration, the director did not want to include "the narrative of the trip as a narrative thread" (Villalobos-Vindas 96). Nevertheless, she decided to present this group of migrants walking at different points of the film. The scenes with them are interspersed with other scenes of different types and genres in the narrative of the film and the subsequent shots show the progress in their route. This is due to the fact that the motif of the journey is integral to the picture of immigration.

Other examples that illustrate the complexity of immigration from the Northern Triangle include individual cases that in the first part illustrate expulsion factors in respective countries of the region. In the subsequent sections of the first part the director discusses the weakness of the governments, military aspects, including American interventionism in the region, corruption, gangs and violence, or environmental destructions as the major reasons behind immigration from Central America. To make those stories more comprehensive and to show how personal cannot be separated from political Villalobos-Vindas intersperses the narrative with documentary footage, official and unofficial snapshots from the past, personal recordings and testimonios.

12 For example, she uses that technique when she presents the extermination of Ixcán in the community of Ixil, Guatemala, where violence, rapes, abuse, and violation of the human rights of the Maya-Ixil group have escalated since the 1970s when oil companies 
began to exploit their native land for the use of the petroleum industry. Their attempts met with a strong opposition of local communities and cooperatives that were hard to defeat legally, as they held land titles. In the face of such challenges the policy of "leveled land" (Casa 7:10) or "scorched earth" (Avendaño 501) was introduced, followed by subsequent massacres of the natives. Massacres and murders triggered migrationpeople were afraid for their lives and decided to flee their land, leaving everything behind and remaining without resources to live. After the second massacre in 1982 "all the people left for the mountains" (Casa 5:00), so the years between 1983 and 1996 witnessed consecutive waves of migration. The viewer learns this story from the testimonio of Marcelino López who is responsible for community organizing in Ixcán. Part of his testimonio is presented as an interview, whereas the remaining fragments are introduced in the voice-over which becomes a commentary on the historical events leading to the forced migration from Guatemala and which is illustrated by intertextual references. For instance, López's description of the massacres is accompanied by the narrative scene of a visit to a local church where the Stations of the Cross are a direct reference to the genocide in Guatemala with Christ represented as one of the natives, and subsequent stations illustrating the army's violence against civilians. The church also houses a wall commemorating those who died in the massacres: there are tiny crosses made of ice-cream sticks with names of those who died, and on top of this wall there is a shelf with ashes of those people. The tribute to the murdered becomes a pretext for a discussion about the extreme social stratification in Guatemala, as it appears these were mainly poor, rural people who were killed and due to that, no reparations have been made (Casa 6:29), since their social status "predestines" them to be ignored by the authorities. Such a conclusion is reinforced by the fragments of documentary records from the trial of President Efraín Ríos Montt that follow the church scene. The first trial recognizes the massacres as genocide and Montt is sentenced to 50 years in prison (Casa 6:52) to a great acclaim of the public. Nevertheless, the sentence is immediately "annulled by the Constitutional Court of Guatemala" (Casa 7:00) only 12 days later, leaving Ríos Montt unpunished. Consequently, as the film informs: "The strategy of 'the leveled land' by the military government resulted in: 200,000 people murdered, 50,000 missing and 1,000,0000 escaping to Mexico" (Casa 7:10), which indicates the extent of the forced migration from Guatemala. The Guatemalan story ends with a voice-over commentary on the government policies and actions that testify to corruption and are not aimed at "the wellbeing of the people" (Casa 7:35), especially in rural areas, which leaves them only with one alternative, migration.

The subsection on El Salvador commences with a series of black-and-white photographs documenting the victims of the civil war with a voice-over from a documentary recording of Monseñor Arnulfo Romero's homily in March 1980, in which he pleads to stop the repressions (Casa 8:11). It constitutes a very powerful introduction to the Salvadorian subsection, as all of the photographs are shocking, but some are particularly horrific, for example those showing children looking at dead bodies of those killed in the war. The sequence of photos is followed by a testimonio of Omar Serrano presented first next to a memorial wall of the victims of the civil war. With his relation he tries to explain the history of the conflict in El Salvador and traces it back to the 1970s, nevertheless emphasizing the pivotal role of the murder of Oscar Arnulfo Romero, "the voice of people" (Casa 8:24), and the subsequent exodus of guerilla fighters to the mountains to fight the regime. This part immediately recognizes the 
role of the United States and the money they transferred to El Salvador-\$1.4 billion spent annually (Casa 8:42)-“to combat leftist movements in Central America" (Casa 8:43). As a result of the conflict, within 12 years about 70, 000 Salvadorians died, mainly civilians "who had nothing to do with the war directly" (Casa 8:57). According to Serrano, this is the first factor that triggered migration, reinforced by the fact that in 2015 , when the interview was conducted, those responsible for the murders were often left unpunished, some of them even had "legal immunity" (Casa 9:49) and became members of Parliament (Casa 9:49). This situation is epitomized by a mural with graffiti on the wall that says: "Evil has deep roots in El Salvador, and if it's not healed completely names will always change, but evil will remain" (Casa 10:00). Similar to other graffiti slogans written all over the world-be it on the Israeli-Palestinian border, on the Berlin Wall, on the U.S.-Mexico fence or on the Confederate monuments in the south of the U.S. or on the walls of buildings in Hong Kong in 2019-graffiti mottos aim at rewriting the official history and complementing it with the voices that have often been silenced in those official accounts.

Based on those two cases it can be seen that Villalobos-Vindas also aims at completing the official history of the immigration from the Northern Triangle. On the one hand, she is very diligent with providing data, statistics, numbers. However, to add to that she includes personal stories of the ordeals, which makes this account more powerful and resonates with the viewer. Such an approach once again forces the viewer to acknowledge the human aspect of historical events or socio-political transformations, which often gets disregarded in the official historiography. At the same time, her stories are far from sentimental-for example, by showing snapshots from the massacres without any commentary whatsoever, she not only pays respect to those who died, but also emphasizes that no commentary is needed in such a situation or even possible. Silence becomes much more powerful than any words that could be spoken here. And at the same time it has to be remembered that silencing has been often part of the history in this region, and as such silence can be interpreted accordingly, as the silence of those who lost their families, homes, or lives in those conflicts.

15 Villalobos-Vindas illustrates the complexity of the immigration from Central America consistently in other parts of the documentary as well, oftentimes focusing on the factors that are not well-known to mainstream audiences, for example, when analyzing the second major cause of forced migration from El Salvador, namely gang violence. The problems with maras (urban gangs) began with the proliferation of "short-term" factories that contributed to the sprawl of impoverished residential neighborhoods. The factories employed mainly women who would go to work, leaving their children on their own in the shacks, with no parental control (Casa 10:56). This, combined with the return of Salvadorians deported from the U.S. who were gang members, for example, in L.A. and who transferred gang structures to El Salvador contributed to the uncontrolled spread of violence. A series of interviews with activists researching gangs and those who have been affected by gangs testifies to the growing power of maras, their destructive influence and divisive role the gangs play in the community.

Departing from the destruction the gangs generate in the neighborhoods in general Villalobos-Vindas supports this image with a case of Patricia Melgar, another interviewee, and her family, since, because of gang violence and bribes he had to pay to gangs, Patricia's husband decided to leave for the U.S. in 2013 and she has never heard 
from him since then. Her story is accompanied by some scenes from their family life. At this point the director introduces some close-ups on the children, who hardly ever smile. What is also striking in this scene is the fact that apart from a young boy there are no men left in this family-it consists of women only. Stephanie Elizondo Griest in Mexican Enough: My Life between the Borderlines discusses an analogical situation in Mexico, where there are some villages in the south with no men at a productive age left, as most of the men, have migrated to the U.S., looking for work. Both Ms. Melgar's story and Griest's account show how immigration influences not only twin cities on the border of the two neighboring countries but it also affects more remote regions in the "expelling" countries. M.a Luisa de Martínez also refers to that phenomenon, referencing statistics, and she argues that in spite of the circumstances in the 1970s not too many people migrated from El Salvador then (Casa 13:45); in the 1980s-"emigration grew, but not considerably" (Casa 13:46). Paradoxically it is after the war ended and since the 1990s that people have been migrating from El Salvador in large numbers (Casa 13:50), which is illustrated by a shot from the bus station and people waiting for buses to take them to the north, including single people, families, young and elderly alike, "with all the suffering that comes with it" (Casa 14:14).

Both in this account and in other stories from the first part the director endeavors to complement the official history and she makes invisible visible, particularly, due to the fact that those stories of migration often begin in remote regions populated usually by poor people whose voices by default are hardly heard. Consequently, she devotes subsequent subsections of the first part to the fight for the land in Bajo Aguán, Honduras, documents the conflicts over land in a Garifuna Community in Barra Vieja, that lasted between 1950 and 2008 (Casa 19:40), she relates the conflict connected with the hydroelectric projects (Casa 26:03) in Huehuetenango, Guatemala, or the destructive mining projects in San José del Golfo (Casa 29:09). The conclusions about the hydroelectric projects may well apply to all the above-mentioned conflicts, as in all the cases the collective action against those projects triggered threats, harassments and attempts to bribe the leaders of local communities (Casa 27:40), which, once again, forced those involved in protests and activism to escape to the U.S. As the documentary reveals: "The World Organization Against Torture conducted an investigation at the national level and the case of Santa Cruz Barillas is here, and the criminalization of the community leaders, which forced them to leave the country to go to the United States because they are persecuted and criminalized" (Casa 28:12).

A similar conclusion is drawn by one of the activists from San José del Golfo, Yolanda Oquelí, who reiterates what is stated on numerous occasions in the film, that in fact in most cases people from Central America do not want to migrate, as migration means first and foremost broken homes and destroyed families. Moreover, when in the U.S. those people are treated as a homogenous group, or even a mass, under the umbrella term "immigrants" and hardly anyone knows their often traumatic stories. They are not welcome there, and instead they are often othered and maltreated. Such an attitude towards migrants illustrates Derrida's concept of hostipitality that combines hospitality and hostility (45). The migrants are guests and enemies at the same time, they are not necessarily welcome and become victims of populism, nationalism and xenophobia, yet at the same time they are to some extent economically needed by the host countries. However, they are feared as well, since in the populist discourse they are aliens that take away the jobs of the locals. As such their status aptly reflects Derrida's seemingly paradoxical theory. Oquelí finishes her testimonio with an overt 
accusation against the "government and multinational corporations" that should be rendered responsible for this situation (Casa 33:14).

Finally, it may also be assumed that the topic of suffering is what links all those tales, as it is the common denominator of migration, regardless of what the "expelling" country is. It is emphasized by Padro Pantoja based on his experience with migrants from Central America. Pantoja reveals the shocking truth "that these migrants don't matter, they're disposable" (Casa 14:28), regardless whether they are from Honduras, Guatemala, El Salvador, and this is what makes the experience of forced migration from individual countries in the Northern Triangle similar. The suffering of migrants from these countries is also aggravated by the specificity of their location, as migration from the Northern Triangle to the U.S. requires a passage through at least one transit country, which automatically increases the risks and dangers of the journey. Due to that, those who undertake this difficult decision do so in most cases being forced by the circumstances, as all the stories from Guatemala, El Salvador and Honduras show, brought to light by the director.

20 Continuing her crusade to reveal the unknown Villalobos-Vindas ventures in the second part of the documentary to the detention center in Mexico, where her interviewees discuss cases of violence, rape, money extortions, thefts of valuables and abuse that befall them. It is not infrequently the officers who are responsible for those violations of the law and who remain unpunished because people are afraid to report them (Casa 50:30), being aware of their status in Mexico-they are not citizens and thus they do not have legal rights to fight against injustice. However, as one of the detainees mentions "at the same time, we are all human, and we all have the right to have opinions, to decide and to question things" (Casa 51:19). These accounts are interspersed with shots from the center where sad and dull colors prevail, underscoring the atmosphere of hopelessness. The scene concludes with a close-up on some scarce toys in the children's area and it is followed by a reference to the problem of family separations and maltreatments in detention centers (Casa 52:07). Here Doris Amador from Honduras talks about how the treatment at the detention center in Mexico affects children in general and how it has affected her daughter who has felt denigrated and humiliated there. Many of such children in the aftermath of their stay at the detention center suffer from PTSD and it is particularly grave, since only between 2013 and 2014 the number of children migrants increased by 117\% (Casa 53:11).

21 It has to be noted here, that with that account Villalobos-Vindas puts herself in a tenuous situation, as she talks openly about cases of abuse on the side of the Mexican law enforcement officers. Even though such stories come to light from time to timesome journalists have also discussed this issue, it has also been part of the fictionalized narrative in the TV series The Bridge (2013-14)-revealing the truth about misdemeanors or corruption of the authorities can put a person at jeopardy. However, in Casa those issues come to light, particularly in the second part of the documentary, and thus once again contribute to the discussion on the complexity of migratory movements in general and forced immigration from the Northern Triangle in particular.

On the other hand, Villalobos-Vindas completes this image of immigration from Central America with more positive stories as well. They are presented in the third part of the documentary, where she focuses on the shelters established along the migratory routes whose aim is to support those in transit. Consequently, "El derecho a la 
esperanza" discusses the question of solidarity and help for those in need. The section begins with the case of Casa Mambré established in the form of a co-op by seven people in 2012. Their aim was to give people a place to get rest, recuperate and prepare for the next parts of the journey in decent conditions (Casa 59:48). Here Vilallobos-Vindas employs an interesting juxtaposition, as she illustrates the account of Socorro López, one of the interviewees, talking about the shelter's purpose with the image of a little girl eating peacefully some food and sitting on the lap of Socorro López (Casa 1:00:20). The viewer does not know if it is Socorro López's daughter or one of the migrants' child, nonetheless, the juxtaposition of the potential danger and the image of an innocent child is to send a clear message to the viewer, and undermine the stereotypical image of an immigrant as a threat, or as the alien "Other."

Throughout those accounts from the shelters the interviewees mention the problems they face, obstacles on the way, or dangers, yet they prefer to focus on the positive side of these institutions. Most of them underline the religious aspect of this help, talking about the obligation they share to support those in need and how it actually fulfills religious doctrines and the words of Jesus. For the helpers it means solidarity with the migrants, regardless of others' attitudes. And such an approach is particularly significant, as those who help do not have substantial means to do so and yet they help because those who are in need are in a much more difficult situation, with their lives often put in danger. Volunteers in another house, Casa del migrante in Piedras Negras established in 1994, also emphasize the "obligation to God to help the people who need it most, in this case the migrants" (Casa 1:01:48). This atmosphere of hope and solidarity is reinforced by the way the scenes from this house are shot: they are sunny and bright-with more saturated colors, as if emphasizing optimism such places are to incite.

24 Nevertheless, similar to all the other aspects concerning migrants, nothing is unequivocal about their status quo. Since some houses are really close to the border it means that people can see al otro lado, but at the same time it often happens that there are people in the house who have been deported from the U.S. and the two groups meet in the house with recent deportees destroying the hopes of other migrants through their stories of failure (Casa 1:02:50). Those hopes are also stifled by the aforementioned increasingly worsened conditions of the journey, due to the increased controls through checkpoints and the militarization of the whole state of Mexico (Casa 1:03:11). Volunteers in shelters in turn, including the aforementioned father Pedro Pantoja, appeal to stop violence against the migrants, abuses and murders (Casa 1:05:11), but at the same time they continue their grassroots work for the cause. Scenes from the houses illustrate the activists' endeavors to provide the migrants both with the necessities they need and with mental and spiritual support to make them feel welcome. They are also encouraged to share their stories, find things they have in common, helping each other in the group and they receive a lot of empowering messages to boost their morale. Help also involves participating in daily activities, so that the migrants feel needed.

One scene in this subsection is particularly powerful when the group led by Pedro Pantoja walk the Stations of the Cross around the city and Father Pantoja not only compares the migrants' fate and journey to the stations of the cross and them to Christ (Casa 1:12:35), but he also emphasizes the need to rewrite history to include them in this new account (Casa 1:14:07). It has to be noted that the stations are adapted to the 
context and the lyrics refer to the fate of migrants, reinforced by collage-like images of those who help and "give them hope that they are not alone, that love and human solidarity still exist, so they may know people with open hearts who embrace strangers with compassion" (Casa 1:16:00). The supplication concludes with a prayer of solidarity and hope (Casa 1:11:56) and the last part itself finishes with the scene of some migrants leaving the house, presumably to continue their journey across the border, juxtaposed with the photo of those who are still staying at Casa del Migrante Saltillo, to give way to the image of the travelers from the beginning of the documentary with an overwritten slogan "no more walls for the right to emigrate and the right to immigrate" (Casa 1:17:33).

Presenting those grassroots projects established by ordinary community members Vilalobos-Vindas indicates positive aspects in the otherwise dim story of migration, focusing on human solidarity and help. She also emphasizes the spiritual (and to some extent religious) aspect of this activism, showing the need to address not only the question of physical well-being of migrants, but also their psychological state. Signaling the importance of the spiritual recuperation, Villalobos-Vindas touches upon the issue that became of particular importance in 2020 with the onset of the Covid-19 pandemic, which has aggravated all the dangers and torments of migratory experience to an unparalleled extent. At the same time she also gives justice to those whose help is often unrecognized and unacknowledged, though it is gradually becoming visible, like the recent project of an artist involved in border activism, Ronald Rael-Pedacito de la Tierra, or A Little Piece of Home. The project commenced on November 11, 2020, when "he and migrant breadmaker Juan Carlos Delgado slid loaves into the first horno, which they built together in Nogales, Mexico" (Larkin 1). The idea behind this grassroots action was to build "hundreds of hornos for migrants waiting in Mexico to receive American asylum" (Larkin 1), both as a way "to honor their heritage and build community in the border shelters" (Larkin 1) through communal work, cooperation and sharing food which, as he says, "reflected the migrant culture currently represented at the shelter" (Larkin 3). The idea behind the project was also to reinforce the naturalness of people's movements and migrations-a concept that has been denied validity especially in the context of the U.S.-Mexico border. And one may argue that Villalobos-Vindas furthers this agenda as well.

Even though the last part of Casa discusses the issues of hope and solidarity with the migrants, it also touches upon the question of the expanding border, since the accounts of both migrants and volunteers refer to the increased restrictions on the flow of people, the growing militarization targeting migrants in Mexico, and the resulting policing of migrants in transit. In this way Villalobos-Vindas illustrates the process that in research is referred to as the creation of the great south border, which is the focus of the second part of this analysis. This process is presented in details in the second part of the documentary, "El derecho a tener derechos" ("The right to have rights"), but in fact the director makes references to this transformation throughout the whole documentary.

The appearance of the expanded southern border has been integral to the antiimmigrant legislation and activities in the U.S., which aggravated after $9 / 11$, as "[t]he war on terror provided the justification for this war on immigrants" (Vargas 376). Zaragosa Vargas conducts a comprehensive analysis of consecutive failures of the American government to pass legislation that would protect Latinx in the U.S., 
including the history of the most well-known initiatives, such as the DREAM Act (377), the DACA program (398), the CAM Refugee/Parole Program (404) and another flagship (failure of) initiative, namely the DAPA program (405). Both Toobin and Vargas emphasize how those legislative endeavors have been accompanied by other measures and programs, including the Operation Streamline (383) or the Border Security, Economic Opportunity and Immigration Modernization Act (400), whose main goal was to scapegoat and penalize immigrants. These initiatives have led to "a shift to state and local restrictive immigration policies and police enforcement" (Vargas 383), which resulted in incarcerations, deportations, increased border security and militarization. Therefore, instead of a "comprehensive immigration reform" (Vargas 406) numerous restrictive measures have been implemented to both deter new migrants from coming over to the U.S. and force to leave those undocumented immigrants who are already there.

It has to be noted that this aggravation of restrictive policies has not been limited to the U.S. territory solely. Failing to control fully the U.S.-Mexico border, the American authorities have decided to extend security measures further down south of the border, in Mexico, which has led to the aforementioned expansion of the border. Laurence Armand French and Magdaleno Manzanares discuss the transformations on the U.S. border in the $21^{\text {st }}$ century and show how the increased border security has transformed the line into a large strip of land, as Mexico has been assigned the "daunting role as a filter for drug and human trafficking" (154). The role of the "buffer zone" (French and Manzanares 157) became more prominent after 9/11, when "Mexico began developing policies aimed at controlling the immigration flows from Central and South America" (French and Manzanares 160). As French and Manzanares argue, "[f]rom that date on, all three Mexican presidential administrations have engaged in one way or another in turning Mexico into a de facto buffer zone between the United States and Central America" (160). However, since this buffer zone has not always been effective, or in fact, it has mostly functioned ineffectively, the U.S. has decided to offer further help to Mexico in order to improve the implementation of security policies there. Consequently, as French and Manzanares conclude, "[t]he overall U.S. security concerns have driven the formulation of policies that now include Mexico in a more prominent role than before, both in terms of national security and immigration concerns. Under the premise of protecting its southern border, the United States is using Mexico as a buffer zone to slow down the migration of Central American unaccompanied children" (165), but the apprehensions do not involve children only. The effects of these policies are already visible, since, for example, "in 2015, there were more Central Americans apprehended and deported by Mexican authorities than by American officials" (French and Manzanares 165). French and Manzanares argue in their analysis that, owing to this strategy "[b]oth countries are becoming increasingly unified due precisely to this Central American socioeconomic reality .... Consequently, Mexico's concerns have shaped its policies toward Central America with the apparent adoption of the American geopolitical objectives as part of Mexico's foreign policy" (154). Moreover, the authors predict that " $\mathrm{t}] \mathrm{he}$ intervening variable represented by Mexico can arguably continue to be significant if Mexico embraces the notion that these transient migrants represent a serious threat to its national security" (165), on condition of "the willingness of the United States to continue offering its neighbor military and other types of assistance and Mexico's disposition to receive such assistance (165). If the two parties continue this cooperation, it will in turn continue 
influencing the geopolitical situation of the region, and the process of the border expansion.

As mentioned before, the second part of the documentary analyzes this process through the discussion of multiple and manifold dangers that the migrants experience on their way to the U.S. and growing migration control in Mexico, owing to which the whole Mexico becomes the great south border for those crossing from Central America, as mentioned above. The director explains how it has been possible to introduce those new control measures in the first place, focusing on the criminalization of migrants, which, combined with scapegoating of "the Other" justifies even the most radical and oftentimes drastic steps undertaken to restrain the flow of people. This part also explains the measures introduced by the U.S. authorities to fund migration control already in Mexico and other transit countries of Central America, which forces the migrants to choose more dangerous routes and leads to more deaths. In this section Villalobos-Vindas also discusses deterring factors that are not mentioned frequently, particularly in official reports on migration, namely assaults, kidnappings, rapes and gang extortions that migrants experience on their way to the U.S. Once again, Villalobos-Vindas completes the official accounts with personal stories of those involved in the transit.

31 The reference to the dangers of the trip can be seen already at the beginning of the section illustrated by the interchange of snapshots from the riding train-known as La Bestia-and the migrants walking, at the backdrop of voices, both male and female, that tell the stories of the journeys full of perils, violence, and horrible deaths, experienced either at the hands of gangs or because of harsh conditions of the journeys. What the interviewees emphasize discussing this issue is the structural and organized type of violence that befalls the migrants. What is more, it often involves the officials and authorities, which makes it less likely to be penalized and which is done on purpose to deter other people from attempting the trip. The analysis of structural violence is intertwined with relations of migrants from different countries from the Northern Triangle who stay at Casa del Migrante in Saltillo, Mexico, and who tell their stories of the journey to el Norte, as if drawing the map of the dangers. Some of them, like Carlos Enrique from Guatemala have experienced violence themselves and that has left them traumatized and completely powerless, all of them have heard of the abuses.

Discussing this aspect, Villalobos-Vindas does not avoid the difficult question about the perpetrators of violence and abuse. Similarly to her depiction of the problems at the detention center in Mexico, examined in the first part of this analysis, here the director once again shows that law-enforcement officers, including train guards, security officers, or even policemen-so people who by definition are expected to be of help-act reversely, not only performing violence but for example, leading the migrants into traps. One of her interviewees, Pedro Pantoja, notes how police violence is paralleled by the organized crime. According to him, since 2008 it has become clear that people disappear through kidnappings (Casa 39:45) both at the hands of gangs and at the hands of the police, which often leads to the massacres of the immigrants he enumerates in the chronological order, starting with "the massacre of the 72 in 2010" (Casa 41:27), "the massacre of Tamaulipas Two in 2011" (Casa 1:33) and "the Cadereyta massacre" in 2012. All of them, he argues, have been meant to "let them get this message" (Casa 41:58) and induce fear among those in transit. His statement is confirmed by individual migrants who have undergone abductions and tortures performed to gain information 
that would allow to extort money (Casa 40:47). Pantoja also evokes statistics from Mexico: they "had registered 9,700 abductions carried out by organized crime with a profit of 25 million dollars' in 2009" (Casa 42:11). President Calderón's reaction to the report was that it was "not enough for the State to do something for the migrants, bring me more" (Casa 42:38), which tellingly shows how dramatic the situation has been and how helpless and powerless the migrants are, facing such accrued adversities on the way to improve their lives.

Pedro Pantoja also mentions the aspect that French and Manzanares discuss in their analysis, namely the (un)official bargaining that takes place between the U.S. and Mexico regarding the restraint of the migrants from Central America. As he admits: "The United States and Mexico are a coalition. Mexico acts slavishly through a deception that they swallowed for some reason: "If you slow down this starving caravan of people, I will let your Mexicans enter"' (Casa 43:09)-the tenuous and dubious declaration that has been apparently challenged by the construction of the wall on the U.S.-Mexico border (Casa 43:47). This operation has been accompanied by the radical change in attitude from the National Institute of Migration, which, as José G. Valdez from Mexico admits, "did not persecute migrants" previously and the number of deportees was lower (Casa 43:51). Valdez argues that "the United States pumped a lot of money into the National Institute of Migration in such a manner that now they have transportation, more personnel, etc. In other words, I think there was a very strong investment from the United States and a lot of political pressure" (Casa 44:20). What José G. Valdez states in this interview has been an open secret for some time now and there are more and more overt allusions to this situation in literature and in research on the migration from Central America. Owing to the increased enforcement of immigration restrictions, which involves the growing number of arrests and deportations of migrants in Mexico itself, the transition of Mexico into the great south border has become a fact.

34 To reinforce the idea of Mexico turning into the border zone both José G. Valdez and Pedro Pantoja emphasize the role of the Mexican government in persecutions of migrants-Valdez identifies two major "sins" of the authorities, including denial to grant the documents that would allow people to take safer routes. The second major problem is that "they [the authorities] grant impunity to all types of criminals to act however they want" (Casa 45: 38). To confirm that accusation Pedro Pantoja evokes a story of a kidnapping from the shelter that took place in 2009 (Casa 46:03). What is striking about this abduction is the fact that, as Pantoja claims, these were the police who kidnapped some migrants staying in the shelter and, once the ransom was paid, they returned to the house. After Pantoja registered the complaint with the authorities they were helpless, as according to them, the police "answer to organized crime" (Casa 46:38). It also is reflected in the structural framework and illustrated by specific data they mention: there are 32 states and 59 detention centers with "more than $\$ 684,000$ spent in 2015 most probably by the National Institute of Migration to control and incarcerate migrants" (Casa 47: 16). ${ }^{2}$

The second part of the documentary finishes with several scenes from deportations where the migrants are sent back from Mexico to the countries of their origin, either by buses or by planes. In those scenes Villalobos-Vindas constantly plays with the viewer-when she projects a scene with the buses driving the migrants to the south the camera focuses on the sign "feliz viaje" standing next to the road (Casa 54:08), which 
gives the scene an ironic undertone. The scenes of deportation are recorded with the voice-over of a person talking about dangers in their home country and perils of the journey. It is intertwined with the scenes where the officer explains the process and procedures of deportation, which once again indicates how tenuous and transitory the migrants' situation is. One day they are in the U.S., working for their living and the other day they are sent back to the country of their origins, with, for example, their family left in the U.S.

In this section Villalobos-Vindas reiterates the idea of specific transformations that have been contributing to the appearance of the great south border. Throughout this part she refers to legislative measures of the U.S. and Mexican governments working as if hand in hand to prevent migration from Central America, combined with unofficial "deterrents" that include violence and abuse that shift the border from the north to the south. Discussing those procedures Villalobos-Vindas indicates both political and personal implications of this change, since the transformation of the actual geopolitical line as we have known it into a large, often militarized, zone has affected both the migrants from Central America and citizens of the neighbor states, including those living further away from the U.S.-Mexico border. The expansion of the U.S.-Mexico border accompanied by the transformation of Mexico into a great south border is of particular significance, as it involves both legal regulations allowing Mexican authorities to apprehend migrants and financial support that maintains institutions and funds actions against migrants.

The atmosphere of all the parts has been reinforced through specific pre-production, production, and post-production techniques deployed by Villalobos-Vindas. She herself discusses the production process in "Ruta de producción Casa en tierra ajena. Documental sobre migración forzada en Centroamérica." As she describes in detail, the pre-production involved selection of the organizations to cooperate with, the recording tours and selection of the equipment to be used during the production (VillalobosVindas 95-97). The production phase involved recording interviews, which originally lasted between 30 and 50 minutes each (Villalobos-Vindas 97). The process of interviewing had to comply with certain premises-first of all, entering the community or the house, the crew were to respect the interviewees and the recording was to take place in dialogue with the person interviewed (Villalobos-Vindas 97). Hence, for example, the interviewees were to choose the place where the interview was conducted, and the "prompts," including photographs, memorabilia, etc. (VillalobosVindas 97). The crew decided to work with natural light (Villalobos-Vindas 97) to avoid artificiality and reflect the real life of the characters in a more authentic way (Villalobos-Vindas 97).

Since some of the places required more discretion during the recording, sometimes the crew used GoPro cameras instead of the usual "Sony NXDCAM, Sony F55, Cannon 5D and Cannon 60 D" (Villalobos-Vindas 96). The choice of the camera was also influenced by the footage, as some of the scenes included civilians' private recordings as well. The stories and testimonies were scripted before in the pre-production process, yet, as it is often the case with recording personal testimonios they were subject to change during the recording, which was later on rearranged in the final assembly. Thus the postproduction phase involved what Villalobos-Vindas calls after Roy Thompson "combined montage" (Villalobos-Vindas 98) which allowed the director to assemble all the 55 interviews into a testimonial documentary (Villalobos-Vindas 98) of 80 minutes, 
instead of the final 120-minute documentary that was first brought for further work to the editing room (Villalobos-Vindas 98). Sound editing at this stage involved both "improvement of the audio quality of some interviews" (Villalobos-Vindas 98) and the choice of type of music, or-reversely-silence, to accompany the testimonies. Consequently, "extremely dramatic musicalizations were avoided, as the testimonies and the stories are impressive enough" and sensationalism was to be avoided when discussing such sensitive topics (Villalobos-Vindas 99). As Villalobos-Vindas concludes her description of the production process, "Casa en tierra ajena ... integrates research, teaching and social action" (101). As such,

[t] he audiovisual language, by its characteristics, allows to carry the content as well as raise awareness about an important topic to diverse audiences and make social science research more accessible. Owing to its approach, it becomes didactic material with applications in various areas (including history, human rights, development, geopolitics, etc.). It is also a tool of social action through the social actions that are incited by its screenings, dissemination and collective dialogue. (Villalobos-Vindas 101)

Finally, the complexity of the migrant experience and the integration of the aforementioned aspects can be fully achieved, owing to a film's transmedia form. Michael R. Ogden attributes the appearance of "transmedia storytelling" (126) to "the convergence of media and information technologies" (125), referring to Jenkins' original definition of both concepts. Analyzing Jenkins' stance on transmedia and subsequent Jenkins' Ford's and Green's distinction between spreadable media and transmedia (126), he argues that "[s]imply stated, transmedia means 'across media"" (126). Quoting Jenkins, he notes that "when combined with the powerful human impulse of storytelling, "[transmedia] storytelling represents a process where integral elements of a [story] get dispersed systematically across multiple delivery channels for the purpose of creating a unified and coordinated entertainment experience [i.e., storyworld]" (126). Lastly, Ogden concludes, "[i]deally, each medium makes its own unique contribution to the unfolding of the story" (126). On the basis of the definition of transmedia storytelling, Ogden identifies the characteristics of a transmedia documentary that in a broad sense can be described as "documentary re-mediated for the internet age" (Nash qtd. in Ogden 128), which becomes reflected in the form of its diffusion and the changing role of a viewer. Consequently, transmedia documentaries are described as "designed with narrative content distributed across multiple platforms as part of an expansive, non-repetitive storyworld. As such, interactive components may be enabled via Web 2.0 technologies, particularly in the context of social concerns that stimulate discourse \&/or invite content contributions" (Nash qtd. in Ogden 133). Villalobos-Vindas herself refers to these characteristics, quoting the definition of a transmedia documentary by Vincente Gosciola where this type of a documentary is "characterized by a narrative structure, or a great story, expanded and divided into fragments that are distributed on various media platforms. The adoption of social networks, such as the blogosphere, and the multiplication of its content from viral and / or interactive processes are also factors present in the transmedia narrative" (Villalobos-Vindas 91). Owing to those features, the viewer of a transmedia documentary is less a recipient and more of the aforementioned '“produser' in discovering the "truth" (actuality) contained in the co-construction of larger storyworlds from the "realities" (potentiality) presented" (Ogden 132). As such the audiences of transmedia documentaries can choose the medium or the platform where 
the story is presented or complete their interpretation of the storyworld by becoming involved in the production of the story via those multiple platforms.

In the case of Casa, as Villalobos-Vindas enumerates, the film is accompanied by a "didactic animation" that "systematizes in a didactic way" the complexities of migration from Central America, a "Youtube channel," a "website," a "Facebook account" and three shorter trailers on Youtube, aside from the official trailer (91). Owing to that, the audience can get more engaged in the story, analyzing it from various perspectives and through different forms, which allows to obtain a more comprehensive and multifaceted image of the events. Apart from that, those versatile forms of diffusion address different audiences and as such they can draw a larger and broader set of viewers. Social media platforms are particularly known to contribute to the popularization of the causes they forward on a large scale, oftentimes worldwide. Even though their impact is usually associated with people of a younger generation, it would be an overgeneralization to state that they only appeal to youngsters. Casa's presence in the social media allows to draw the attention to the topic of forced immigration from the Northern Triangle on a broader scale, as it reaches people all over the world who would otherwise not realize the scope of the problem. The animation in turn presents these events in a way more appealing to younger audiences. Finally, as Villalobos-Vindas admits, thanks to this form, Casa makes "social science research more accessible. Owing to its approach, it becomes didactic material with applications in various areas (including history, human rights, development, geopolitics etc.). It is also a tool of social action through the social interactions that are generated by its screenings, diffusion and collective dialogue" (101).

In her representation of the complex and multifaceted character of forced migration from Central America Villalobos-Vindas both provides a detailed analysis of the phenomenon, placing it against historical and socio-political background, and completes the official accounts with personal stories and testimonios, which oftentimes reveal the unknown (and ugly) underbelly of migratory movements in the region. Those personal stories also emphasize human aspect of political and historical events or transformations, bringing to light the fate of ordinary people befallen by history and affected by a particular geopolitical situation in which they happen to live. Analyzing emigration from individual countries in the Northern Triangle Villalobos-Vindas identifies both similarities and differences in the migration patterns, based on specific examples from Guatemala, El Salvador and Honduras. In this way, not overgeneralizing, but drawing analogies from those individual cases the film adopts a regional approach in order to understand better why people from this part of the world migrate in such large numbers to the U.S., which also contributes to the discussion on the geopolitical situation in this hemisphere. This analysis is completed through the examination of the process of Mexico becoming the great south border, or the "buffer zone" (French and Manzanares 157) for the U.S., owing to which Villalobos-Vindas once again rewrites or completes the narrative on migration from Central America, showing how "terror came from the north" (Gordon 1). And even though the first months of 2021 witnessed "a sharp drop in [immigration] arrests" in the U.S., owing to "President Biden's orders to rein in U.S. Immigration and Customs Enforcement" (Miroff and Sacchetti), those decisions have already been met with criticism and lawsuits have been filed. For now, as Miroff and Sacchetti note, "Biden is under pressure from immigrant and advocacy groups galvanized during the Trump administration who want to see ICE 
transformed if not dissolved" ("Immigration arrests"). The Covid-19 pandemic also changed the dynamic of deportations from the U.S., as "the agency took steps to protect its officers from potential exposure to the coronavirus while also reducing occupancy levels at immigration jails" (Miroff and Sacchetti "Immigration arrests"). Nevertheless, growing criticism of the Biden administration and legal actions already undertaken in some states, including, for example, Texas, may suggest that the question of immigration from Central America in the years to come will retain its sinusoid character, as Casa en tierra ajena aptly depicts.

\section{BIBLIOGRAPHY}

Avendaño Quesada, Florencia. “Casa en tierra ajena. Un documental sobre migración forzada en América Central. Producción: Ivannia Vilallobos Vindas y Carlos Sandoval García. Dirección: Ivannia Vilallobos Vindas. Basado en libro No más muros. Exclusión y migración forzada en Centroamérica de Carlos Sandoval García. Costa Rica: UCR-UNED-CONARE, 2016, 80 MIN." Anuario de Estudios Centroamericanos 43, (2017): 499-503.

The Bridge. Developed by Meredith Stiehm and Elwood Reid. FX, 2013-2014.

Cantú, Francisco. "Boundary Conditions: What happens when the American frontier becomes a wall?" The New Yorker, March 11, 2019, pp. 73-77.

Casa en tierra ajena. Directed by Ivannia Villalobos-Vindas, 2016.

Derrida, Jacques. Of Hospitality: Anne Dufourmantelle Invites Jacques Derrida to Respond. Translated by Rachel Bowbly, Stanford UP, 2000.

French, Laurence Armand, and Magdaleno Manzanares. North American Border Conflicts: Race, Politics, and Ethics. Taylor and Francis, 2017.

García Sandoval, Carlos. Exclusion and Forced Migration in Central America: No More Walls, Palgrave, 2017.

---. No más muros. Exclusión y migración forzada en Centroamérica. Universidad de Costa Rica, 2015.

Gordon, Rebecca. “What Happens in El Norte. Doesn't Stay in El Norte.” Tomgram: Rebecca Gordon, How the U.S. Created the Central American immigration Crisis, 15 Aug. 2019, www.tomdispatch.com. Accessed 15 Apr. 2021.

Griest, Elizondo Sthepahnie. Mexican Enough: My Life between the Borderlines. Washington Square P, 2008.

Johnson, Tory. "What the Government Considers the US Border May Surprise You." Immigration Impact, 19 Oct. 2018. www.immigrationimpact.com. Accessed 15 Dec. 2020.

Larkin, Ximena N. "The Architect Baking Bread Along the Border Wall.” Atlas Obscura, 11 Feb. 2021, www.atlasobscura.com. Accessed 20 Feb. 2021.

Miroff, Nick and Maria Sacchetti. "Immigration arrests have fallen sharply under Biden, ICE data show." The Washington Post, 9 March 2021, www.washingtonpost.com, Accessed 17 March 2021. 
Ogden, Michael R. "Interactive/Transmedia Documentary: Convergence Culture Meets Actuality Storytelling.” Interin, vol. 25 n.1, Jan. / June 2020, pp. 121-138.

PBS. “Francisco Cantú: ‘The Line Becomes a River.” PBS, 20 March 2019, www.pbs.org/wnet/ amanpour-and-company/video/francisco-cantu-the-line-becomes-a-river. Accessed 20 March 2021.

Stillman, Sarah. "Where are the Children? For extortionists undocumented migrants have become big business" The New Yorker, 27 April 2015, pp. 40-53.

Thompson, Roy. Manual de montaje. Plot Ediciones, 2001.

Toobin, Jeffrey. “American limbo: While politicians block reform, what is happening to immigrant families?” The New Yorker, 27 July 2015, pp. 30-35.

Vargas, Zaragosa. Crucible of Struggle: A History of Mexican Americans from Colonial Times to the Present Era. U of North Carolina P, 2017.

Villalobos-Vindas, Ivannia. (2017), "Ruta de producción Casa en tierra ajena. Documental sobre migración forzada en Centroamérica” Investiga UNED, 2017, pp. 88-103.

\section{NOTES}

1. All translations throughout the article are mine, unless stated otherwise.

2. The numbers have increased since 2015.

\section{ABSTRACTS}

The question of the U.S.-Mexico border has been discussed extensively by various media in different contexts, particularly within the last few years and the focus of those publications has ranged from legislative issues, through militarization of the border and the resulting criminalization of migrants to the growing number of deportations and conditions in detention centers. Those exemplary cases of border stories related recently in the media signal the shift in immigration patterns from Central America and consequences of those changes for the whole region. They also demonstrate the trajectory of transformations at the U.S.-Mexico border, including the change of the concept of the border from la linea separating two nation-states into an ever-expanding zone that exceeds political lines and turns Mexico into the great south border. These issues are discussed in the documentary Casa en tierra ajena or Home in a Foreign Land (2016) directed by Ivannia Villalobos-Vindas and the purpose of the article is to examine how Villalobos-Vindas addresses the complexity of the process of forced migration from Central America and to analyze how the documentary illustrates the appearance of the expanding border or the transformation of the U.S.-Mexico political line into the great south border. 
INDEX

Keywords: U.S.-Mexico border, immigration, Casa en tierra ajena, doumentary, media representation

\section{AUTHOR}

\section{EWA ANTOSZEK}

Ewa Antoszek is an Assistant Professor at Maria Curie-Skłodowska University in Lublin. Her current research examines Latinx authors and artists (re)writing the border. She is the author of Out of the Margins: Identity Formation in Contemporary Chicana Writings (Peter Lang, 2012). 